\title{
Karel Kachyňa
}

\author{
By Boris Jachnin \\ Fall 1995 Issue of KINEMA
}

\section{KAREL KACHYŇA: FOUR DECADES OF A GREAT CZECH DIRECTOR}

\section{Decade One: The Beginnings}

It is difficult to give a foreign viewer a satisfactory picture of Karel Kachyňa," a director who lets the viewer experience humour, grief, joy and education from such simple things as a tree, a cloud or plain earth in such a limited number of his films. Kachyna made his first film in 1950 for his final work at the Prague Film Academy when he was 26 years old. He was born in 1924 into a Moravian family from the small town of Vyskov. In this part of Moravia almost everybody paints and sculpts. ${ }^{(1)}$ All the houses are beautifully decorated and every village has its experts on painting Easter eggs. As he was growing up, Kachyna painted and photographed more and more eagerly. He always finished every work he started. But when one is 16 and the schools are closed because of Hitler's occupation and one has to do forced labour in a German factory, a future as a photographer seems very far away. ${ }^{(2)}$

But Kachyna was a determined young man. After the war he went to study at the new Academy of Arts in Prague, serving the most attractive of the Muses, film. He studied both camera and directing with another Moravian, Vojtěch Jasný. ${ }^{(3)}$ They graduated with a film they made together. The optimistic title The Clouds Will Roll Away (Není stále zamračeno, 1950) exactly expresses the mood of the picture. In this semidocumentary story, professional actors and students were cast with real workers on a farm somewhere near the Czech-German border where, after the war and after the deportation of three million Sudeten-Germans, hordes of enthusiasts, adventurers and crooked carpetbaggers began their new lives in the vacated territory.

The message of the film was optimistic, and it had to be, in an age when pessimism was politically incorrect. František Daniel, who studied at the Moscow Film Academy co-operated with Kachyña and Jasný on the scenario. Kachyňa and Jasný directed, shot and cut the film. ${ }^{(4)}$

In those days they were the among the first postwar graduates and were somewhat older than present ones since they had lost a year or two at the front or, if they were lucky, in a Nazi labour camp. Jasný and Kachyňa continued to work in tandem. Their optimistic films were about people who wanted to do productive work in the first years of liberty.

Productivity was a subject of conversation of their young heroes even while making love, or rather instead of it, because love was seen as something too private and even reactionary to belong in film. The young female members of the Communist youth organisation helped to combat sexuality by wearing flat shoes, boyish blue shirts and being politically conscious.

Today, people laugh at these simplistic stories, and that's a good thing. But sometimes there is also real indignation about the director's endorsement of the regime's ideology during the post-war years. How does Kachyna react to it? He never gets upset -- he just nods. It is the nodding of a man who cannot be surprised by any disaster because he has always expected it. It also contains a certain type of humour, not too loud or showy. It is the humour of silence and of exact, simple sentences. If one did not know that Kachyna comes from the country of wine and deeply-rooted folk traditions, one would say his humour has very British dimensions.

One day Kachyna was given chits allowing him to shoot films (these chits were most important under socialism: Milos Forman, who only had chits for writing scenarios, could not get a camera from the studio and had to shoot his first film with his own equipment). Kachyňa went to China with Vojtěch Jasný where they shot -- on the orders of the Czechoslovak Army -- a series of reports about Chinese soldiers. They made several films full of political clichés but with beautiful visual compositions. When the political climate changed and Chinese soldiers ceased to be Czechoslovakia's beloved brothers, these films were all banned at once. But nobody would use the word "ban" then. The films were simply "withdrawn from circulation." 
Everything was so simple. From the moment that filmmaking was nationalized -- as early as 1945 -- all activities connected with film were centralized. ${ }^{(5)}$

This centralization made it possible for the government to keep everything under control. Not only the distribution of finance but also every written word and every metre of film. That was, in February 1948, the beginning of an era in which aesthetics became subordinated to political directives of the Communist Party. Shortly after, the megalomaniac apologist for Stalin's policy of Socialist Realism, the Soviet director Mikhail Chiaureli, arrived at the Prague Barrandov film studios to shoot his Fall of Berlin (1950).

In this atmosphere Kachyňa's and Jasný's The Clouds Will Roll Away looked like a fresh gust of cinéma vérité or maybe Italian Neorealism. The freshness of view was only later deformed, according to a young film critic at the time, under party pressure which forced the filmmakers to produce works filled with contrived pathos. Pathos had always been a foreign element in Czech film: Czechs had no use for bunting, because the flags they had to honour were often not their own but were usually those of their larger neighbours, whether they liked it or not. So Czech art had to find various ways to communicate very intimately with the audience: through mystification, parody, and demythologisation of grand concepts.

Under socialism, the educative function of art was promoted as the new order's main aim. "Film is the most important of all arts," Vladimir I. Lenin is said to have declared, and the general director of the Czechoslovak state film had this slogan printed on the letterhead of his writing paper. One can hide a lot behind such a slogan. The market value of film was suppressed ("only in capitalism does one measure art in terms of money") and the small national film industry produced films of great importance -- which nobody wanted to see.

Kachyňa and Jasný split up in the late fifties and each of them went his own way. Were their concepts and directions completely different? It did not seem so. However, Karel Kachyňa has always tended to work with a partner, enjoying the support, tension and control between them. Nevertheless he needs to be the one who gives the film the final shape. He actually needs a literary partner who can guard the ground plan of the script, one who can write firmly hewn and innerly rich characters. Since 1959, when Kachyňa made his famous King of the Šumava (Král S̆umavy), he has always been a co-writer of the scenario but has directed it himself. On the other hand, Jasný was also an independent and ambitious director and could not remain in the role of Kachyňa's literary collaborator forever.

Kachyňa soon found his new theme in his King of the Šumava, a film which also made him famous. It was a cult film for a young generation whose idols had been denied to them -- the scout organisation, for example, had been declared an enemy movement and Westerns had disappeared from the Czech cinemas. Here they saw a thriller about men guarding the borders without uttering political platitudes, supplied instead with a romantic hero, wild nature and well-dosed tension. The success of the film lasted for many years.

King of the Šumava already disclosed the main components of Kachyňa's style. He is in his element when he can rely on the script (he has never written his own story). He not only modifies another writer's text, he often even changes it completely and visualizes scenes written as dialogues. Kachyňa likes a sequence of film images without verbal stuffing. He is extremely strong in the scenes when images move the story forward.

Sometimes critics blame him for being too obsessed by this visual expressiveness. They criticize him for hiding weak parts of a scenario with visual ornamentation -- could it be the influence of Moravian decorated houses and Easter eggs? Actually Kachyňa only plays visual tricks in those moments of the film where the script wears thin. In his best films one never finds a single ornament which hampers the story or which only tries to please the viewer. Kachyňa hates to repeat things; he tries to avoid it even by not automatically casting an actor into a role in which he was once successful. He is a screen test fanatic; he does them even with the most famous actors -- those who have more than fifty films to their name - or a hundred. Some of them, whose every wrinkle is known and loved by the audience, do not understand. They seem to think: "Doesn't he know my films? Is this director crazy?"

Once one of Kachyňa's students at the Film Academy was making a film about a famous actor. His professor asked how it was going. The student said with fear in his eyes: "It is not going well. It's out of control. The Maestro plays ... well, he simply plays something else." 
Kachyňa nodded of course. "Did you do screen tests? I always told you to do the tests."

The young talent blinked his swollen eyelids. "How could I? With the Maestro?" "Yes. Precisely with him," Kachyňa said. "You should always do the tests. With everybody!"

"I will, I will for sure," the young man repeated. "But what shall I do now? Could you please..."

Kachyňa nodded - this habit must be quite irritating for some people. "You must tell him you made a mistake. That you need a different actor!"

The young man refused to consider such a situation. "Tell the Maestro...?"

"Yes!" said Kachyňa a bit impatiently. "Tell the Maestro or whoever plays it. It is your film, isn't it? You must be satisfied with it. Always start with the tests. Go to him and stop being mad at him and me, we are not to blame!"

In the late Fifties Kachyňa did not yet teach at the Academy. He was starting his series of films for children -- a theme which returns frequently in his films. It was a time when the positive hero of socialist films was gradually being replaced by an anti-hero. One could see less and less of those healthy athletes who lived to a happy ending. They were succeeded by real people with real problems as if the authors ceased to be obsessed by "the world around us" and started to scrutinise "the world within ourselves." Undoubtedly there were many external influences which contributed to this change, beginning with the political turnaround after the revelation of Stalin's crimes, through the cultural situation in Europe and the birth of the French New Wave.

The participation of Czechoslovakia in the Brussels EXPO in 1958 was also very important. Karel Zeman's Invention of Destruction (Vynález zkázy, 1957) won the Grand Prix there; the experimental Laterna Magica ${ }^{(6)}$ and Polyekran ${ }^{(7)}$ by the brothers Alfred and Emil Radok ${ }^{(8)}$ brought them much success. Before their exile Alfred Radok managed to help Milos Forman and other talented individuals, at least those who did not have to emigrate. Czech art had traditionally been connected by an umbilical cord with its political exiles and there were always enough of them.

At the end of the Fifties the situation of Czechoslovak film worsened as several films were banned for political reasons. ${ }^{(9)}$ On the other hand, this nonsensical, publicly proclaimed ban united many film-makers in protest. That was when Karel Kachyňa met Jan Procházka.

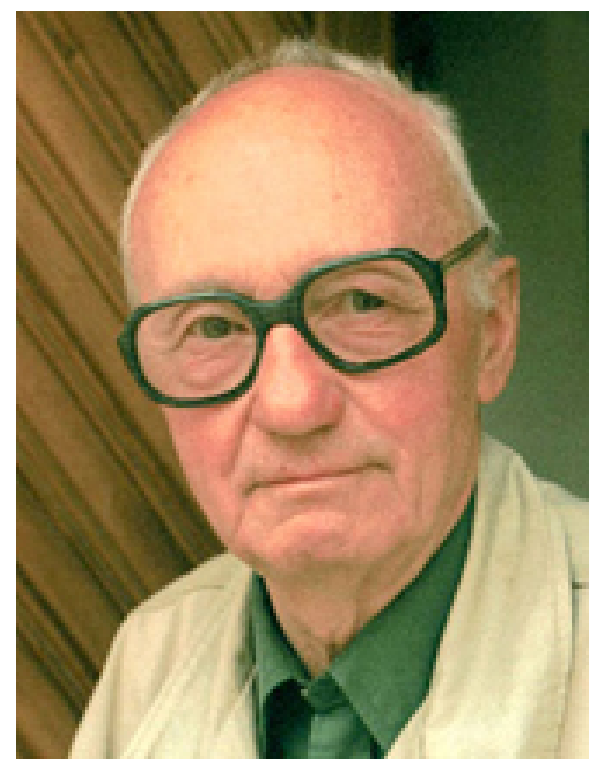

Figure 1: Director Karel Kachyňa (1924-2004)

Decade Two: Intimate Tragedies about Life under Socialism 
Jan Procházka (1929-1971) was of Moravian farmers' stock and an enthusiastic functionary of the Communist Youth Organisation, a builder of collective farms. His first book of reports describing this milieu was a disaster. After this failure he was silent for years; his next book published in 1960 won him a literary prize.

Prochazka soon started to write film scenarios. The first film he made with Kachyňa, Fetters (Pouta, 1961), was not a great success but soon after that they started a remarkable series of lyrical films about young girls growing up. The most successful of them was Suffering (Trápení, 1961).

Hope (Naděje, 1963), a shocking and exceptional film at the time, started a so-called "black" series of films which were openly critical of society. Hope is a story of two outcasts who officially did not exist under Socialism -- an alcoholic and a prostitute. Prochazka added a little spark of light into their hearts which society always quenched, and kindled with such care as any, even the smallest, hope deserves. A tramp, Lucin -- a living chronicle of Socialist building sites and plants -- is an unreliable old lag. His counterpart is the half tipsy Magdalena, whose house serves as a refuge for lonely pub deserters. Their love story is as thin as a curl of smoke from a smouldering rag. Lucin humiliates Magdalena because others humiliate him. Will he come back to her? The film does not give an answer. Perhaps only by its promising title. For the leading roles Kachyna chose a great character actor, Rudolf Hrušínský, and a singer Hana Hegerová -- a very unconventional combination indeed.

Kachyňa then started to film scenarios by Procházka who, being incredibly productive, not only supplied other film directors with his themes but also published his own book, wrote critical articles for youth newspapers and still managed to be active in politics. Karel Kachyňa worked exclusively with Procházka for ten years; the twelve films they made together were strikingly better than those Procházka made with other directors.

In the 20th anniversary year of the liberation of the Czechoslovak Republic (for the most part by the Red Army), they made a film called Long Live the Republic! (At žije republika!, 1965). In those days, anniversaries were used for making big films (especially in the Soviet Union). However, Long Live the Republic! was a very exceptional and unconventional case. Even its title was intentionally ironic. Prochazka's most important text up to that point, it reflects his own memories of childhood together with the scepticism of a 36-year-oldwriter. The story demythologises the legend of victory. It is narrated by a twelve-year-old outsider, despised by other children for not belonging to the class of rich farmer families. His own father thinks it is necessary to beat him every day.

Many have asked how it was possible that the otherwise strict political censorship tolerated the provocations of this creative couple. The fact that Prochazka was a significant political authority certainly played an important role here: he was a member of the Central Committee of the Communist Party where he had made it to the top, thanks to his articles and his popularity among young people. He was even a friend of the President, Antonín Novotný, who used to invite him for chats at Prague castle whenever the Party got into trouble with writers and filmmakers. But the general political climate was also changing. More and more reformists started to appear at the top of the Communist Party.

Struggling with problems, often close to a catastrophe and a ban on working, the artistic level of Kachyna and Procházka's controversial films gradually increased. In 1966 they made Coach to Vienna (Koč́r do Vídně, 1966), arguably their most controversial film dealing with a subject which was always a strict taboo in socialist Czechoslovakia: the darker side of the guerilla ("partisan") movement during World War II.

The film was discussed at the top and was banned during shooting. But Prochazka pressured the President to let Kachyna finish his film. At the Karlovy Vary (Carlsbad) Film Festival, there was complete silence during and after the screening and the audience seemed shocked. Offering no trace of the liberating humour of the previous film, the ambiguous truth of Coach to Vienna resulted in disillusionment. The reviewers refused to accept its central idea. Only the Polish critic Boleslaw Michalek underlined the general validity of this film which is about ethics -- not only in connection with a concrete story from the Second World War but about war as such in which everybody is necessarily a victim.

In their best films, Procházka and Kachyňa revealed the truth about their country and people through the wrong side of the official doctrine; the politically-correct side appeared inferior and false in their films. Outsiders definitively replaced heroes - in the end, the entire nation was an outsider. 
In 1967 the Procházka-Kachyňa film series continued with another drama constructed as a biblical legend -Holy Night (Svatá noc). Both authors returned to the theme of forced collectivization of agriculture which they had portrayed with such naive optimism some years before. Risking their professional future they managed to clear their names with this mature film.

"The weeks of higher pill consumption, the nights of the long cigars are here..." (Prochazka). In that period Kachyna probably got used to troubles and learned to accept them with a shrug. During the day he was shooting, at night he was in the mixing room waiting for Procházka's telephone calls. "They said..." -- "They concluded..." -- "It is not completely lost yet..." -- "In any case you should finish it, then we'll see..."

They were not alone though, since the Czechoslovak New wave was at its zenith, uniting various generations of film-makers and writers. This close connection between film and literature probably had several motivations: film-makers needed the exact formulation of moral problems of their time. Writers met this wish because they found out that film adaptation helped to create a wider audience for their work.

In 1967, the [then] prominent dissident Václav Havel was asked by a group of film-makers to read a Protest letter at the Conference of the Association of Czechoslovak Writers. Some Members of Parliament called these directors "enemies of working people" because their films were unintelligible or offensive. Film-makers defended their right to free expression. Soon after this, the so-called Prague Spring followed, resulting in the invasion of the Warsaw Pact armies on 21 August 1968, ostensibly to defend Socialism against counterrevolution.

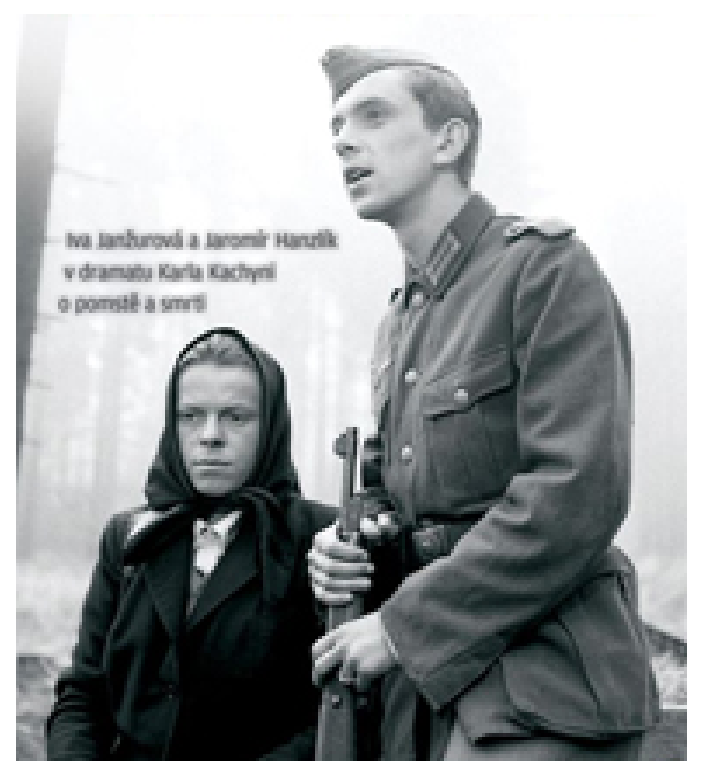

Figure 2: Kachyňa's controversial Coach to Vienna (1966)

\section{Decade Three: It Will Always Be Cloudy}

Kachyňa and Procházka made two films which are among the best of this period. Funny Old Man (Směšný pán, 1969) was completed right after the invasion and was only distributed for a short period. A 60-year-old cyberneticist, who used to be imprisoned in a Stalinist concentration camp, undergoes heart surgery. He can live again but has no hope of getting his work and family back; a bitter film which ends with a hopeful message.

The Ear (Ucho, 1970) was the last film in the series of the authors' intimately-stylised allegories. It was immediately banned and only premiered when the twenty-year-old "normalization" regime of Gustav Husak fell apart. ${ }^{(10)}$

Procházka was deprived of an opportunity to work and fell ill. His last joint film with Kachyňa, an adaptation of a children's book by the Australian writer, Alan Marshall, could not appear under Procházka's name. Instead, Ota Hofman, their friend and colleague, was credited as the scenario writer of Jumping Over 


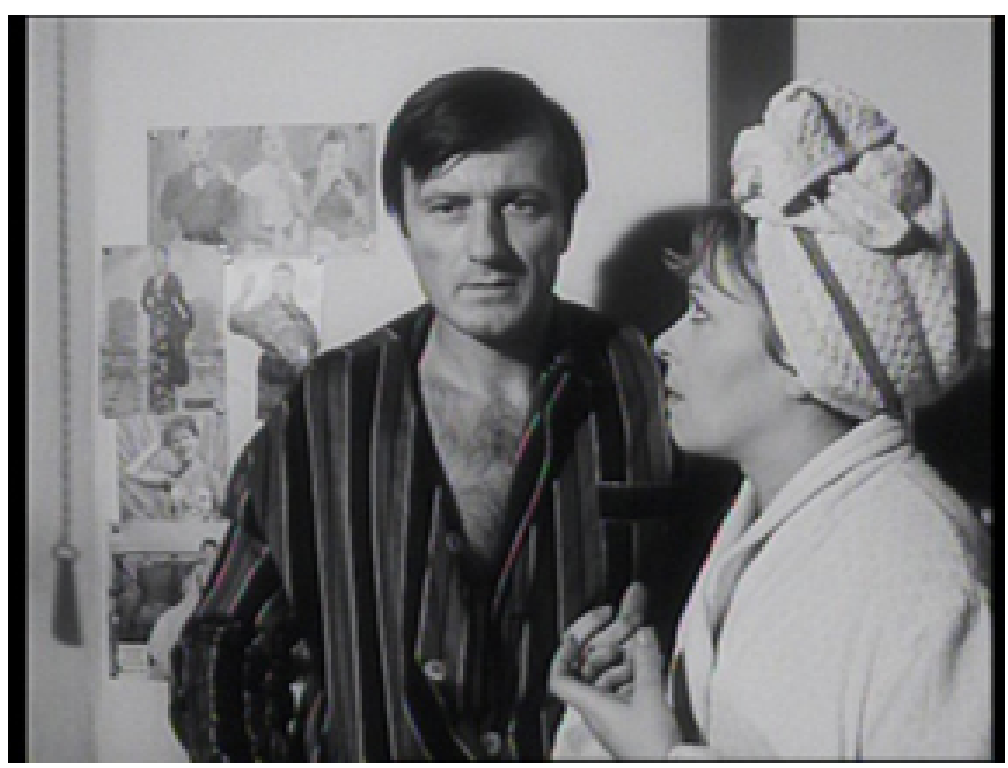

Figure 3: Radoslav Brzobohatý and Jiřina Bohdalová (The Ear, 1970)

Puddles Again (Už zase skáču přes kaluže, 1970). The film enjoyed success in many countries though its impact must have been weakened on the foreign viewer, since the feeling of identification with the main character, a disabled boy, was a major connotation. After the 1968 invasion, most Czechoslovak viewers felt that the boy's faith in his recovery was a metaphor for them all.

There were many more film stories found in Procházka's legacy, but Kachyňa had to wait for another twenty years before he was allowed to use them. Soon after the invasion, in 1969, Kachyňa was fired from the Academy, apparently as the result of a tragicomic circumstance. One of his students had made a film titled Uninvited Guest about an alien who disturbs the life of a married couple. In this popular film, the irresistible comedian Pavel Landovský plays the leading role to the enthusiastic approval of audiences.

The only problem was that Kachyña was the Professor of the talented young director; consequently, he was invited to see the Police. They claimed that the uninvited guest in the film was a reference to the presence of Soviet troops on Czechoslovak territory. Kachyna pointed out to the police that the script for this film had been in existence long before the invasion, and the reference was only coincidental but this did not convince them. As a result, Kachyna was not allowed to teach any more.

The next film Kachyňa made after this incident was a costume biography of Alexander Dumas: The Secret of a Great Storyteller (1972). The introductory comments to the script read: "Dumas' characters are honest, straightforward and brave." Still this was not playing it safe enough. The actor (Martin Štěpánek) who played in it fled the country. The name of an émigré artist simply could not appear in the credits; thus, the film was put on ice. ${ }^{(11)}$

When the exhausted Procházka died, Kachyňa started to look for a new partner, but fate took one friend after another from him. He lost Ota Pavel, Rudolf Kalčík and Dušan Hamšík. He outlived Jan Otčenášek and Ota Hofman. Death took them away and then took his wife as well.

It seems quite incredible that in this difficult period he made several films which stood out over the film production of many years: Love Between Raindrops (Láska mezi kapkami deště, 1979), and two films after the stories of Ota Pavel, Golden Eels (Zlati úhoři, 1985) and The Death of Beautiful Deer (Smrt krásných srncü, 1986), the film versions of Adolf Branald's Watch Out, the Rounds! (Vizita, 1981) and The Nurses (Sestričky, 1983).

\section{Decade Four: Czech Film-making}

Needless to say, when democracy returned to Czechoslovakia after the Velvet Revolution of November 1989, 
Kachyňa was offered a job at the Prague Film Academy once again and all his films were taken out of the vaults together with those by Jiří Menzel, Pavel Juráček, Jaromil Jireš, Vojtěch Jasný, Ján Kadár and Elmar Klos, Alfred Radok, Věra Chytilová, Miloš Forman, Ivan Passer, Zdeněk Sirový and others; director Hynek Bočan could even finish his incomplete film after twenty years. Everything returned to normal. But was it really normal?

Many artists returned from exile (excluding Forman, the Paris-based writer Milan Kundera and Jasný); many were politically and professionally exonerated. Paradoxically, Otakar Votoček who had emigrated to Holland as an expert on nuclear chemistry reappeared in his home country twenty years later as the director of an excellent film, Wings of Fame (1990), starring Peter O'Toole, Colin Firth, and Andrea Ferreol. Now it was important to dismantle the colossal state organisations which hampered real enterprise and had made the development of a market economy and healthy competition impossible.

In 1990 the central management of Czechoslovak film was abolished and the avalanche it caused shook the film industry. Film production was separated from distribution. Several small studios and new organisations were founded. The old production and distribution structures fell apart without any replacement. The whole process was further complicated by other momentous political changes, long-lasting negotiations about new laws concerning privatisation and finally the unfortunate division of the republic. Cinema attendances dropped radically; film material, technical equipment and various services became increasingly expensive; the invasion of American action films now filled the gaps in the education of many; and, finally, new and poor television stations were opening, in the hope of getting rich by broadcasting cheap American pulp.

As of now, the annual film production has fallen from thirty-five to approximately half but films are still being made, although nobody understands where the money comes from. However, the new system of state grants has already started. Audiences are also getting tired of car chases and space inhabitants and they feel like enjoying a good film again. In 1990 Kachyňa could finally complete his Czech-French co-production film The Last Butterfly about Jewish prisoners and in particular about children in the Theresienstadt ghetto. This is an unusually big production for Kachyňa. It deals with a painful subject which has been tackled in Czech films at least twice before: in Radok's genial Long Journey (Daleká cesta, 1949 -- which has practically not been screened for 40 years) and Zbyněk Brynych's Transport from Paradise (Transport z ráje, 1962). ${ }^{(12)}$

The next Kachyňa film, Santa Claus Is Coming To Town (1991), was financed by Czech television. It was a scenario found in Procházka's legacy and Kachyna was supposed to have made it twenty years earlier. It is a warm story of an outsider who is as young as Olin (Long Live the Republic), rootless like Lucin (Hope), and it takes place in a hospital (like High Wall, Attention, Watch Out, the Rounds!, Counting Sheep, The Nurses, Funny Old Man, and many others) -- a hospital is always filled with a lot of outsiders. This particular outsider is of a fighting kind, a Robin Hood in pyjamas.

In 1992 Kachyňa was able to work on another scenario which Prochazka had prepared for him years ago. It is an adaptation of an earlier Jan Procházka's novel, a work with a strong humanistic impact, called Kráva (The Cow, 1994). Kachyňa and his new collaborator (since 1978) Karel Čabrádek adapted the scenario and again made the film with television money. This time Kachyňa chose young people to work with him: a very talented Petr Hojda as director of photography, Radek Holub, an actor from an avant-garde Prague theatre, and the actress Alena Mihulová who played the leading role in The Nurses. The Cow is a simple story about the hard life of poor village people, about passion, and the beauty and cruelty of nature. The Cow is not only the most mature and stylistically pure of Karel Kachyňa's films, it is also a caveat for a society which once promised to leave the cold waiting room of Socialism for a better future, only to suddenly find itself in a messy marketplace impersonating an international trade centre. The manifest excellence of The Cow brought the filmmaker several awards, including the Grand Prize at the 1994 Strasbourg Film Festival. For Kachyňa The Cow has a special significance because Alena Mihulová, the leading actress, became his wife.

But Kachyňa did not rest. He started the seventh decade of his life with a five-part television series Swell Season (Prima sezóna, 1994). The book was written by one of the most important Czech postwar authors, Josef Škvorecký (living in Toronto, Canada). Now Kachyňa plans to film Julia after Bohuslav Martinů's opera. He also wants to film the novel I Was Waiting on an English King (Obsluhoval jsem anglickeho krále) by Bohumil Hrabal (Hrabal's Closely Watched Trains were filmed by Menzel in 1968). It is still very difficult to find money to realise upcoming projects. Will the economic restrictions be more difficult for Kachyña 
than the political censorship? One can guess but there is only one way to find out.

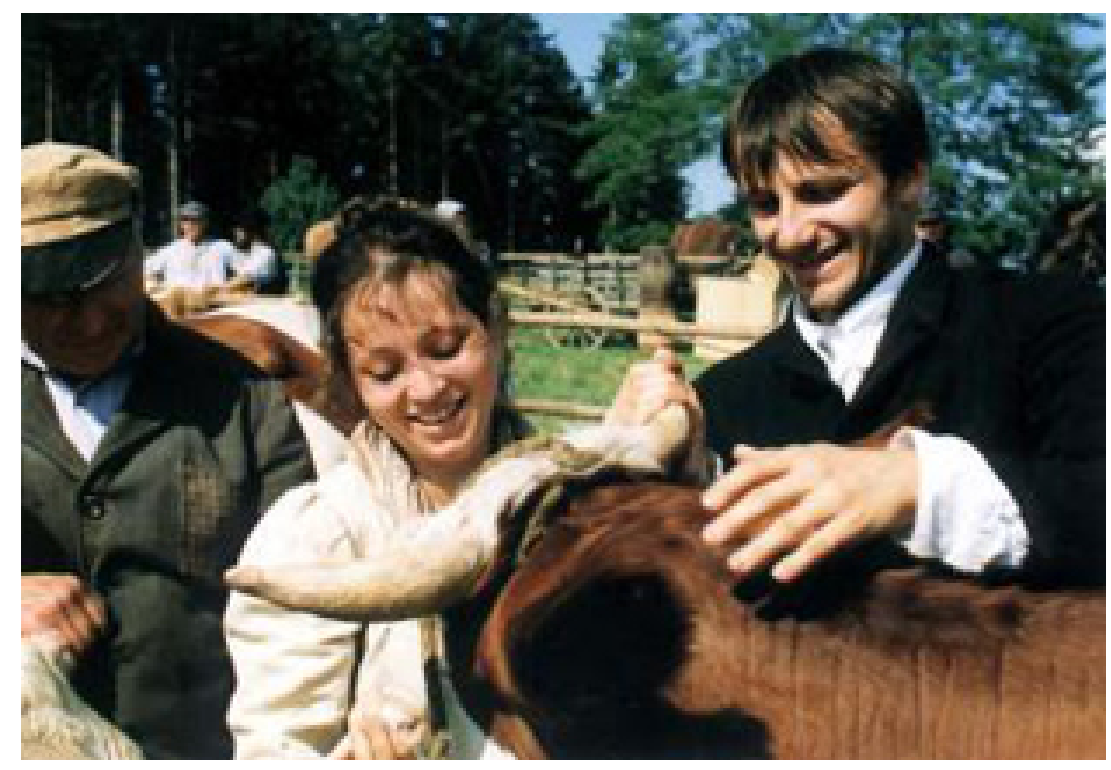

Figure 4: Radek Holub and Alena Mihulová (The Cow, 1994)

\section{Notes}

1. Moravia was, together with Bohemia, one of the historical Czech Crown Lands. Today, its autonomy gone, the name designates only an administrative region; nevertheless, there are non-negligeable cultural differences between Bohemia and Moravia (both Czech-speaking), with characteristic local customs, music, folk artforms, and architecture.

2. In October 1939, shortly after the occupation of Czechoslovakia, the Nazis closed all Czech universities. They remained closed until 1945.

3. Jasný's films include Desire (Touha, 1958) and All My Good Countrymen (Všichni dobři rodáci, 1968).

4. It is worth mentioning that two members of this trio (Daniel and Jasný) are now teaching at North American film schools.

5. The film production industry was the first of all industries to be nationalized (1945).

6. In this experimental system, film projection was ingeniously blended with live performances.

7. An early multi-screen projection system.

8. Emil Radok died in Canada in 1994.

9. These restrictions followed the so-called State conference at Banská Bystrica (1959).

10. It was released after 1989 together with a number of previously banned films in a series called "films from the vault."

11. In some exceptional cases, a film could be screened without credits -- but only when it was possible to edit out the entire role of the undesirable person out of a film. Encyclopedias and monographs published at that time by the Czechoslovak Film Institute simply omitted many films and filmmakers. Some of these publications left out several of Kachyna's films, in others some actors' names were missing...

12. These two films had originally problems with distribution. The Communist regime was just as antisemitic as the Nazis, though it had never been officially admitted. 


\section{References}

\section{Literature}

Goulding, Daniel J. ed. Post New Wave Cinema in the Soviet Union and Eastern Europe. Bloomington: Indiana University Press, 1989.

Hames, Peter. The Czechoslovak New Wave. Los Angeles: University of California Press, 1985.

"Karel Kachyňa." International Directory of Films and Filmmakers (2). Chicago: St. James Press, 1991. Pp. 436-437.

Liehm, Antonín J. Closely Watched Films. New York: IASP, 1974.

Liehm, Mira and Antonín J. Liehm. The Most Important Art: East European Film After 1945. Berkeley: University of California Press, 1977.

Škvorecký, Josef. All the Bright Young Men and Women. Toronto: Peter Martin Associates, 1971.

Žalman, Jan. "Everyone a Good Fellow-Countryman," International Film Guide 1970, London: Tantivy, 1970, s. 83-84.

\section{Author Information}

Boris JACHNIN (CSc from Charles University), teaches at the Universities of České Budějovice (Budweis) and Zlín, Czech Republic. A Prague Film Academy (FAMU) graduate in Film Theory, he was forbidden under the Communist regime to publish, for political reasons. His 1987 book Rainer W. Fassbinder was published under the alias Jan Grulich; under his own name: Charles Chaplin, Brigitte Bardot, and Jan Procházka (all by Czech Film Institute). For his critical biography Walt Disney, Prof. Jachnin received the 1990 Prize of the 